\title{
GEOMORPHOLOGY AND SEDIMENTOLOGICAL PROCESSES ALONG THE COASTAL ZONE BETWEEN LIVANATES AND AGIOS KONSTANTINOS (N. EVOIKOS GULF, CENTRAL GREECE)
}

\author{
Tsanakas K. ${ }^{1}$, Gaki-Papanastassiou K. ${ }^{2}$, Poulos S.E. ${ }^{3}$ and Maroukian H. ${ }^{4}$ \\ ${ }^{1}$ National and Kapodistrian University of Athens, Faculty of Geology and Geoenvironment, \\ Department of Geography and Climatology, 15784 Athens, Greece, ktsanakas@geol.uoa.gr \\ ${ }^{2}$ National and Kapodistrian University of Athens, Faculty of Geology and Geoenvironment, \\ Department of Geography and Climatology, 15784 Athens, Greece, gaki@geol.uoa.gr \\ ${ }^{3}$ National and Kapodistrian University of Athens, Faculty of Geology and Geoenvironment, \\ Department of Geography and Climatology, 15784 Athens, Greece,poulos@geol.uoa.gr \\ ${ }^{4}$ National and Kapodistrian University of Athens, Faculty of Geology and Geoenvironment, \\ Department of Geography and Climatology, 15784 Athens, Greece, maroukian@geol.uoa.gr
}

\begin{abstract}
This study deals with aspects of geomorphology and nearshore marine processes in the coastal zone located between Livanates and Agios Konstantinos (North Evoikos Gulf, central Greece). Evoikos Gulf is a tectonic graben bounded by WNW-ESE trending normal faults; it can be further characterized as semi-closed marine basin with water depths exceeding 400m.The Coastal geomorphology is affected by active tectonics with the most prominent morphological features being the uplifted marine terraces and the well-developed deltaic fan of Xerias torrent. In the present investigation, detailed geomorphological mapping at a scale of 1:5000 was performed together with granulometric analysis, while nearshore wave and current activity related to sediment dynamics has been determined on the basis of wind-generated wave regime. The examined coastal zone consists of a series of alluvial cones and fans, Xerias fan being the largest among them, low cliffs, a cuspate foreland and beach zones of limited length, often hosting beachrock formations. The formation and evolution of the study area seems to be controlled by the limited terrestrial influxes, the relatively weak wave regime due to limited wave fetches distances, and the associated longshore currents that induces limited sediment transport.
\end{abstract}

Key words: geomorphology, sediment dynamics, coastal erosion, tectonic activity, North Evoikos Gulf, Central Greece.

\section{Introduction}

Coastal environments are formed and evolved as the combined effect of endogenic and exogenic processes. This study attempts to invetigate the terrestrial and marine processes combined with the neotectonic acticity that lead to the formation and evolution of the coastal zone between Livanates and Agios Konstantinos that belongs to the North Evoikos Gulf, central Greece (Fig. 1).

The study area lies along the west coast of North Evoikos Gulf and is bounded southwards by Mt. Kserovouni (841m) and Mt. Knimis (726m), and westwards by the delta fan of Xerias torrent. The 


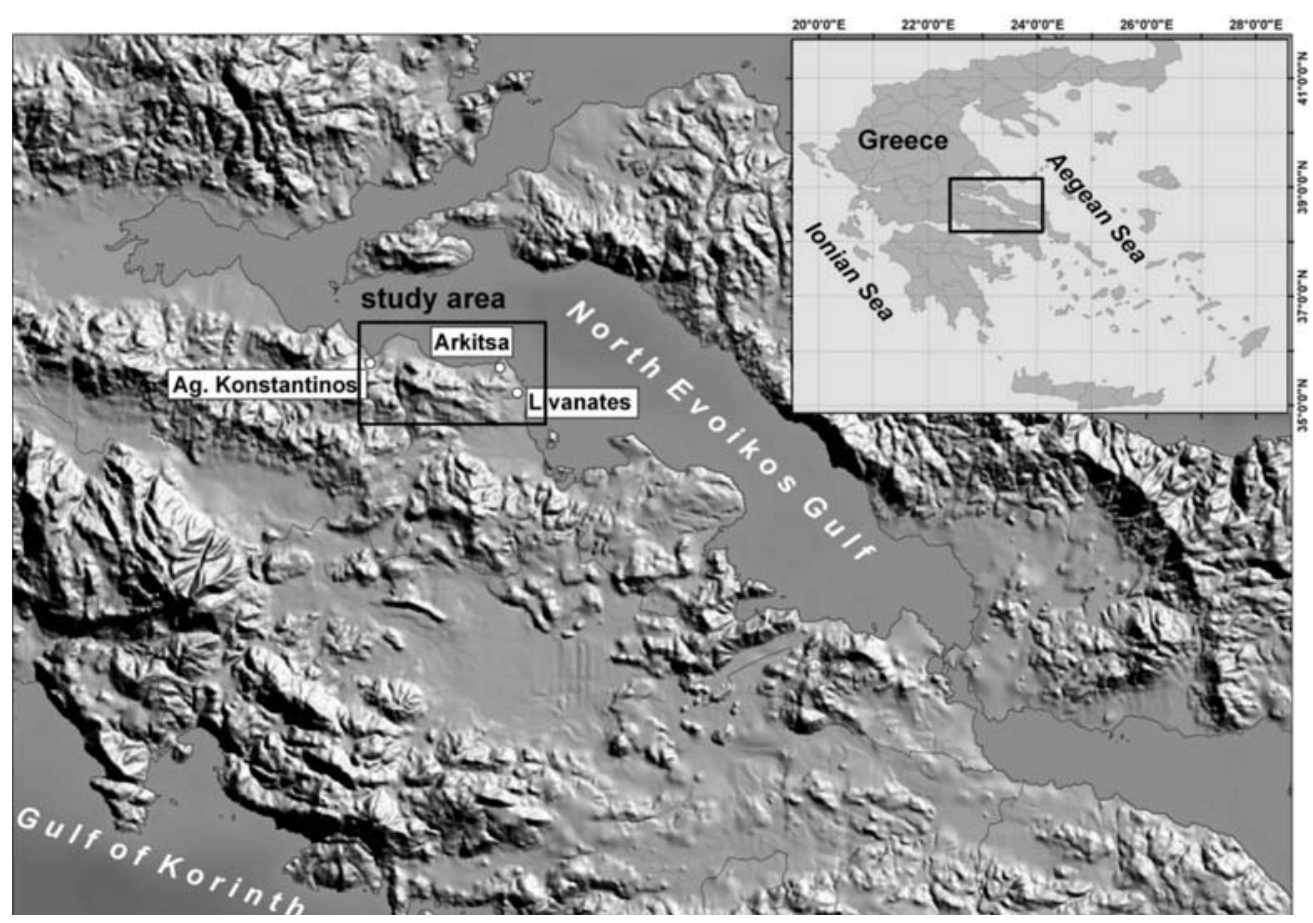

Fig. 1: Location map of the broader region of the study area.
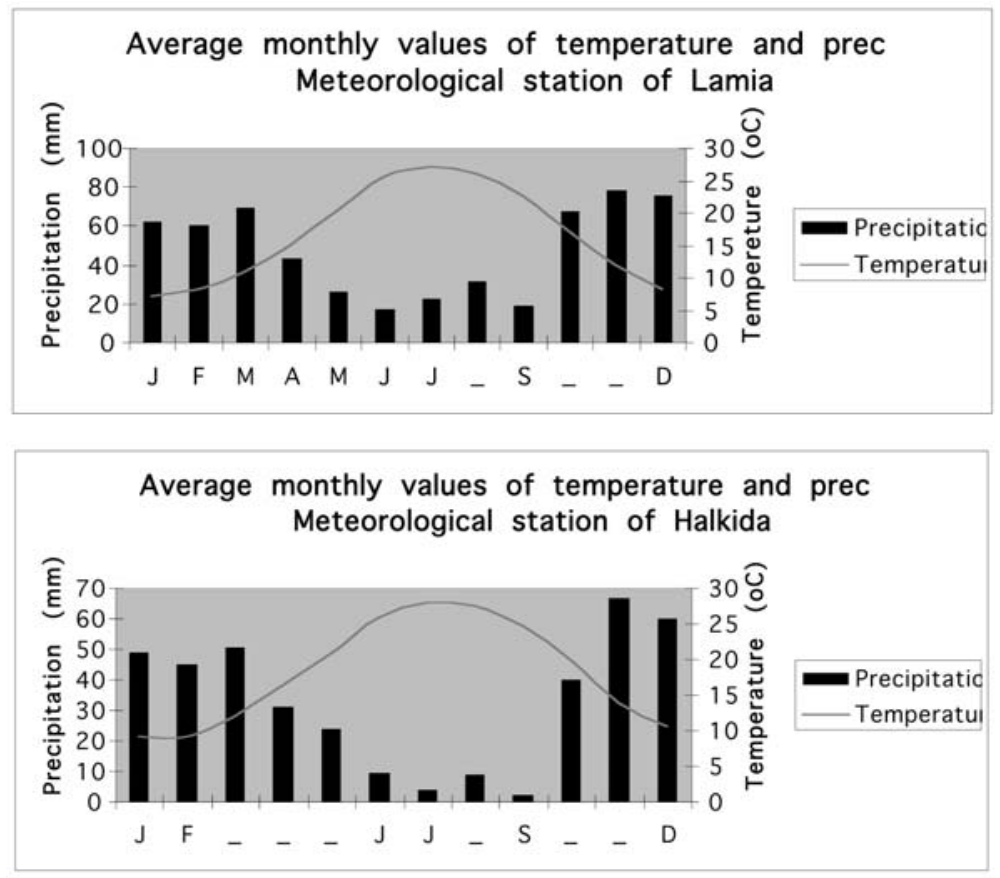

Fig. 2: Average monthly values of temperatures and precipitation (data obtained from Lamia and Halkida meteorological stations, HNMS, 1964-1994). 


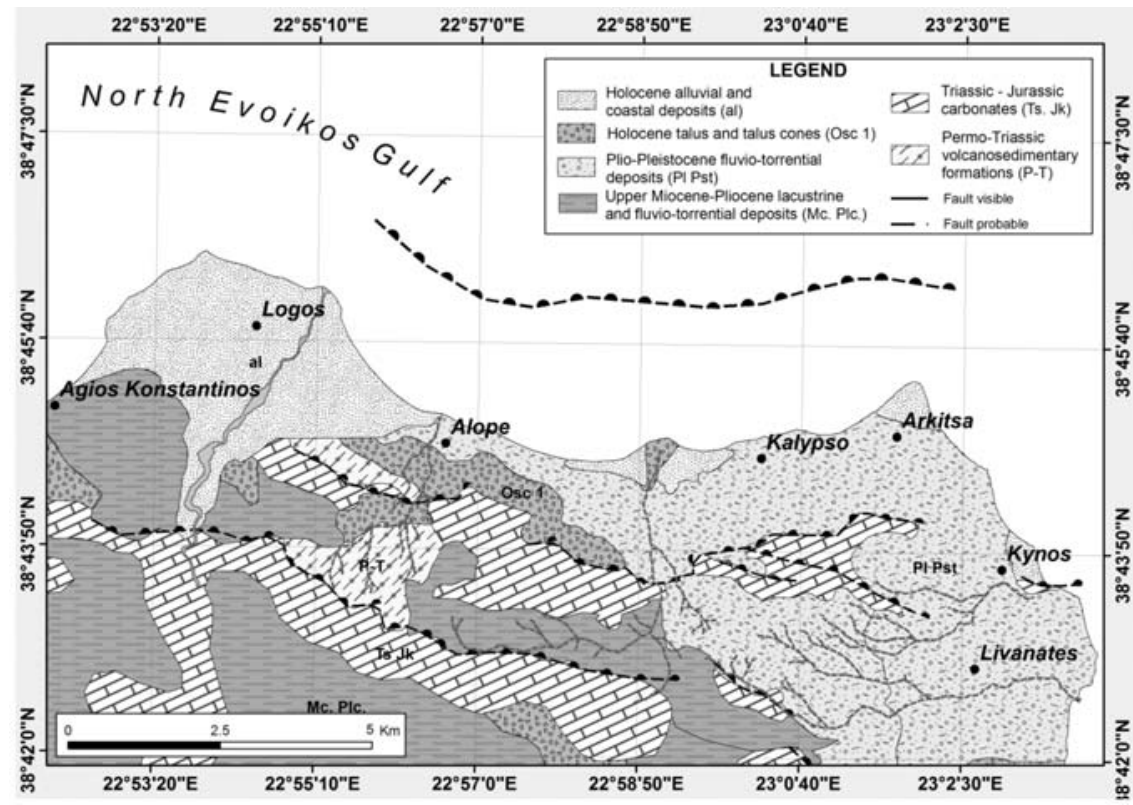

Fig. 3: Geological map of the study area based on the maps by IGME (2006) and field work.

total shoreline length is $25.3 \mathrm{~km}$ hosting the mouths of 5 torrents, between them Xerias in the west being the most significant in terms of size and sediment discharge. According to Woodward (1995) the area under investigation undergoes weathering processes that may produce annually 100-200 $\mathrm{tn} / \mathrm{km}^{2}$ of its drainage basin.

Geomorphological and sedimentological processes are related to the prevailing climatological setting. Air temperature as well as precipitation are major factors that designate weathering and erosion rates, while wind speed direction and frequency are the main factors that control the wave regime in a coastal area thus controlling the coastal morphology. Hence, air temperature and precipitation data were obtained from two meteorological stations (Halkida and Lamia) of the Hellenic National Meteorological Service. Data analysis shows an average annual temperature of $16.5^{\circ} \mathrm{C}$ and $573.3 \mathrm{~mm}$ of annual precipitation for Lamia station and $18{ }^{\circ} \mathrm{C}$ and $390.2 \mathrm{~mm}$ for Halkida station respectively (Fig. 2).

\section{Geological and Tectonic setting}

Since the Upper Miocene to present, the area of Central Greece has been affected by ongoing active crustal extension in a NNE-SSW direction, mainly by two major mechanisms: the westward motion of the Anatolia plate, and the slab retreat (roll-back) of the African slab under the Hellenic Peninsula (Armijio et al, 1996; Meijer and Wortel 1997; Doutsos and Kokkalas 2001). The structure of this area of Greece is dominated by a series of roughly WNW-ESE-trending extensional faults (accommodating extension of $15-20 \mathrm{~mm} / \mathrm{y}$ ) which have created a series of semi- asymmetric, grabens (Eliet et al, 1995). The most prominent of these extensional structures are the Gulf of Corinth and the Evoikos Gulf, both of which are WNW-ESE trending graben systems about $100 \mathrm{~km}$ long, and are bordered by N-dipping master faults, that are usually segmented along their strike giving a step type morphology (Roberts, et al., 1991; Westaway, 1991; Doutsos and Poulimenos, 1992; Roberts and Koukouvelas, 1996; Kokkalas et al., 2006; van Andel et al., 2006). 
Table 1. Wave fetch distances $(\mathrm{F})$ and offshore angle of wave crestline with respect to coastline $\left(\mathrm{a}_{0}\right)$ for each of the five (A-E) sub-units (positive direction is towards the East).

\begin{tabular}{|c|c|c|c|c|c|c|c|c|c|c|}
\hline & \multicolumn{2}{|c|}{ UNIT A } & \multicolumn{2}{c|}{ UNIT B } & \multicolumn{2}{c|}{ UNIT C } & \multicolumn{2}{c|}{ UNIT D } & \multicolumn{2}{c|}{ UNIT E } \\
\hline & $\mathbf{F}(\mathbf{m})$ & $\mathbf{a}_{\mathbf{0}}\left({ }^{\mathbf{}}\right)$ & $\mathbf{F}(\mathbf{m})$ & $\mathbf{a}_{\mathbf{0}}\left({ }^{\mathbf{}}\right)$ & $\mathbf{F}(\mathbf{m})$ & $\mathbf{a}_{\mathbf{0}}\left(^{(}\right)$ & $\mathbf{F}(\mathbf{m})$ & $\left.\mathbf{a}_{\mathbf{0}} \mathbf{(}^{\mathbf{}}\right)$ & $\mathbf{F}(\mathbf{m})$ & $\mathbf{a}_{\mathbf{0}}\left({ }^{\circ}\right)$ \\
\hline $\mathbf{W}$ & 4470 & 40 & - & - & - & - & - & - & - & - \\
\hline $\mathbf{N W}$ & 7940 & 5 & 9050 & 40 & 12300 & 63 & 12800 & 35 & - & - \\
\hline $\mathbf{N}$ & 7300 & -50 & 7070 & 5 & 9490 & 18 & 14800 & -10 & 12700 & 65 \\
\hline $\mathbf{N E}$ & - & - & 14900 & -40 & 13800 & -22 & 15300 & -35 & 16700 & 20 \\
\hline $\mathbf{E}$ & - & - & 34000 & -85 & 2300 & -67 & - & - & 26800 & -25 \\
\hline
\end{tabular}

The study area belongs to the Pelagonian zone of Central Greece. This unit, lying above a Variscan basement, comprises transgressional clastic and carbonate sediments of Early/Late Permian age and Early to Middle Triassic carbonates (Guernet, 1971; Clément, 1983; Baud et al., 1991). The local lithology (Fig. 3) consists of Permo-Triassic volcano-sedimentary formations, Triassic-Jurassic carbonates and Neogene and Quaternary formations composed of lacustrine, fluvio-torrential and marine deposits.

\section{Methodology}

In this study topographic maps were obtained at a scale of 1:50.000 and 1:5000 issued by the Hellenic Army Service. In order to examine the influence of the terrestrial and marine processes and to draw conclusions relating to the Quaternary landscape evolution of the study area, detailed geomorphological mapping at a scale of 1:5.000 was performed focusing on the landforms along the coastline. In addition, the coastal slope, sediment size, beachrock formations, coastal stability and longshore drift were also mapped. Data were analysed using GIS technology. A Digital Elevation Model (DEM) of the area was also created from 1:5000 topographic diagrams. The cell size of the grid was $10 \mathrm{~m}$ and the software used for this analysis was Arc-GIS v9.3 and Arc Seen v 9.3.

With respect to the coastal wind generated wave regime which governs the nearshore sediment transport and in the absence of wave records, wave characteristics have been estimated at the basis of the prognostic equations of the shore protection manual of the US Army Corps of Engineers (CEM, 1984) utilising the wind data set obtained from the nearby Halkida meteorological station from the Hellenic National Meteorological Service.

Following, the longshore component (onshore to breaking zone) of the wave power per unit length of the shoreline is calculated on the basis of the offshore predicted wave characteristics, assuming a rather uniform nearshore seabed morphology using the equation (CEM, 1994):

$$
\mathrm{Pl}=0.058 * \mathrm{Q} * \mathrm{~g}^{3 / 2} * \mathrm{Ho}^{5 / 2} *\left(\cos \mathrm{a}_{0}\right)^{1 / 4} * \sin 2 \mathrm{a}_{0}
$$

Where, $\varrho$ is the density of seawater $\left(=1025 \mathrm{~kg} / \mathrm{m}^{3}\right), \mathrm{g}=9.81 \mathrm{~m} / \mathrm{sec}^{2}$, Ho the offshore wave height and $\mathrm{a}_{0}$ the angle of wave crest line with respect to shoreline. The above calculation, due to the variety of coastline orientation has been applied to different units of the coastal area under investigation, as shown in Fig. 6. (for values see Table 1). 
The potential rate of longshore sediment transport by volume $\left(\mathrm{Q}_{1}\right)$ for sand-sized grains has been determined by the empirically derived equation (Komar, 1978):

$$
Q_{l}=\frac{0.39 \times P_{L}}{g \times(\sigma-\rho) \times 0.6}
$$

$\mathrm{Q}_{1}$ is measured in $\mathrm{m}^{3} / \mathrm{s}$, s and $\varrho\left(\mathrm{kg} / \mathrm{m}^{3}\right)$ are the densities of sediment $\left(=2650 \mathrm{~kg} / \mathrm{m}^{3}\right)$ and water $\left(1025 \mathrm{~kg} / \mathrm{m}^{3}\right)$, respectively; $\mathrm{P}_{\mathrm{L}}$ is the longshore component of the incoming wave power (Watt $/ \mathrm{m}$ of wave crest) given by equation $1 ; 0.39$ is a coefficient of efficiency relating to loss of water due to percolation through the sediments, and 0.6 is another coefficient which represents the average proportion of the bulk sediment occupied by particles, rather than pore space. In accordance to the above, $\mathrm{Q}_{1}$ values have been calculated separately for the different sub-units for all the predominant wind/wave directions per each sub-unit.

\section{Results and discussion}

\subsection{Geomorphology}

The combination of active tectonics and global variations of sea level during the late Pleistocene has led to the formation of at least three uplifted marine terraces, which correspond to high sea level stands (Fig. 4). The lower and the most recent terrace (A) lies in between $2 \mathrm{~m}$ and $20 \mathrm{~m}$ of altitude. The second terrace (B) is found at elevations of 20-40m elevations and the third one (C) at 40-60m. These marine terraces have been formed on Plio-Pleistocene marls. For the lowest (A) and the middle terrace (B) a cap rock formation has been found overlying uncomformaly the Plio-Pleistocene marls; it consist of beach material (sand, pebbles, cobbles and marine fossils). Unbeatably, these coastal landforms indicate Neotectonic activity on the broader study area and could be used as sea level indicators.

The coastline of the investigation area hosts the alluvial fan of the Xerias torrent to the west, another two much smaller cones at its central part and the Arkitsa promontory towards its eastern end. The latter seems to have been formed in earlier stages of sea level stands (as shown by the nearshore bathymetry) and being shaped either by tectonic activity and/or by the operation of a previously active mouth of a torrent.

Furthermore, along the shore zone, a series of coastal landforms has been found that indicate recent (Holocene) tectonic uplift (Pirazzoli, 1996; Gaki-Papanastasiou et al, 1999) as characteristically shown on Figure 5. These include extended and under subaerial erosion beach rock formations (Fig. 5a) marine notches (Fig. 5b) and sea caves (Fig. 5c) along the northern part of the coastal area.

An analogous uplift movement has been denoted at Alope region by the presence of an alluvial cone of Holocene age which lies on top of a layer that consists of beach material (Fig. 5d). This beach material of late Holocene (Roman) age is uplifted at elevations $>1 \mathrm{~m}$ asl. which suggests significant coastal uplift since Roman times (Cundy et al, 2009).

\subsection{Nearshore marine and sedimentological processes}

In the microtidal environment of the North Evoikos Gulf the wind generated waves play the main role between the nearshore marine processes. Thus, from the Table 2, where the predicted 


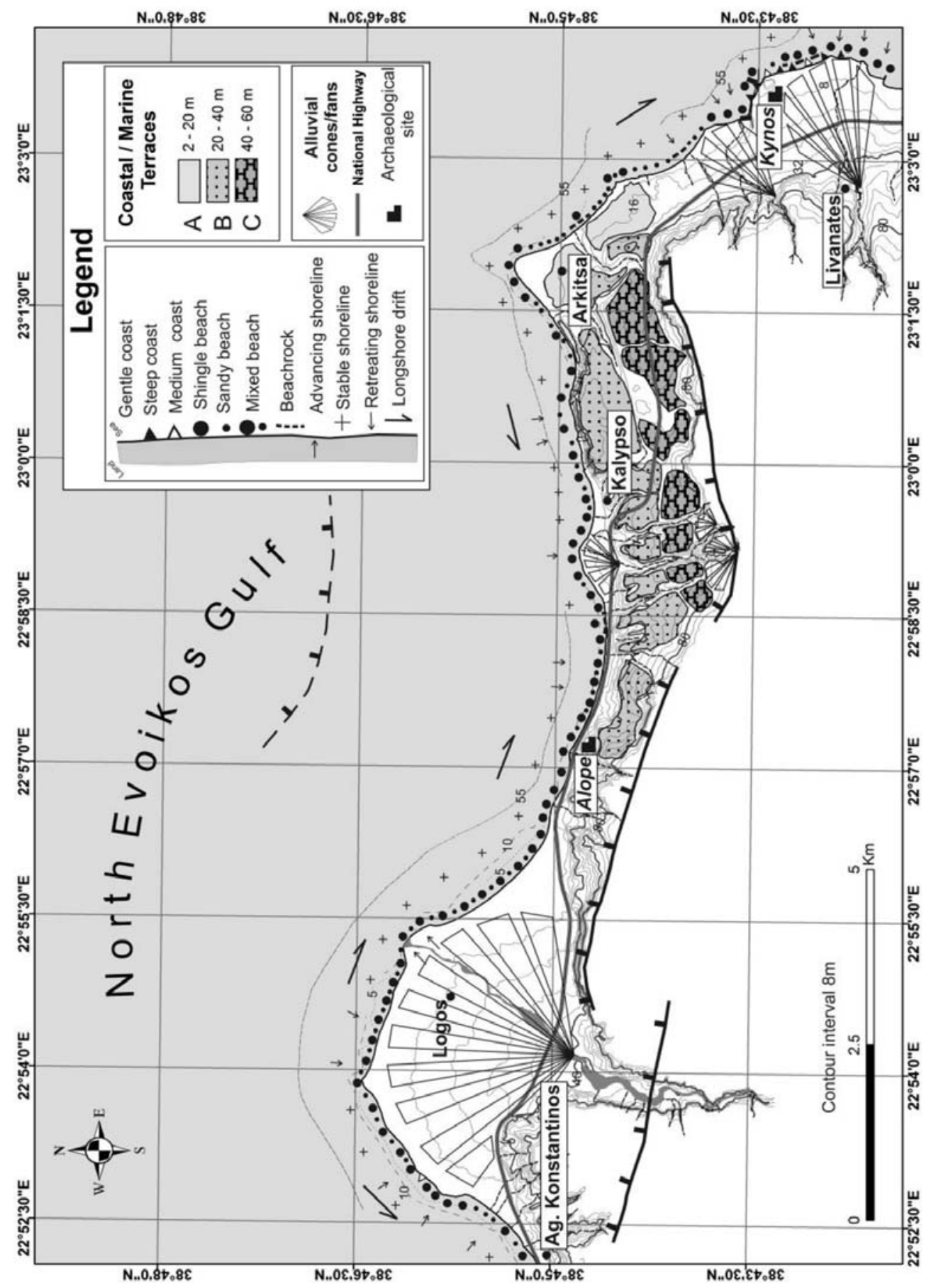

Fig. 4: Gemorphological map of the study area depicting among others, the coastal features along the shoreline, the granulometry as observed on the field and the longshore drift (Cundy et al,, 2009). 

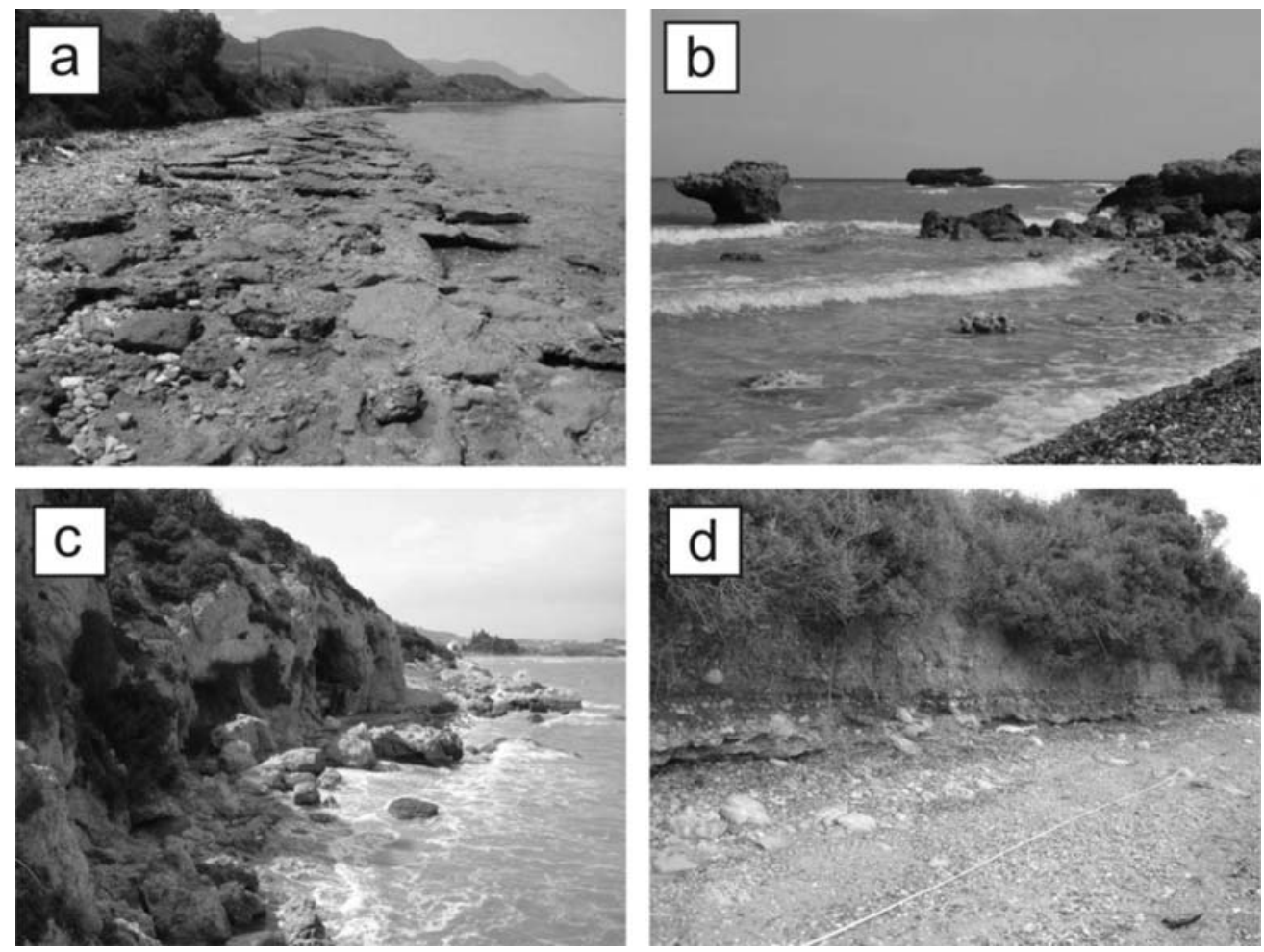

Fig. 5: (a) Uplifted and eroding beachrocks at Kalypso; (b) Uplifted (by $1 \mathrm{~m}$ asl) marine notch at Kynos; (c) Uplifted (approx. 2m asl) sea caves at Kynos; and (d) Eroding coastal alluvial cone at Alope. The base of this cliff consists of well cemented beach material, uplifted $>1 \mathrm{~m}$ asl since Roman times.

offshore wave characteristics are presented, it can be seen that the coastal area under investigation undergoes a rather weak wave regime (average wave heights are $<0.5 \mathrm{~m}$ and periods $<3 \mathrm{sec}$ ) due to the semi enclosed (restricted wave-fetch distances) character of the North Evoikos Gulf. This nearshore wave climate is associated with a low capability of longshore sediment transport, i.e. the calculated potential annual values are $<1200 \mathrm{~m}^{3} / \mathrm{yr}$ (Table 3), when those refer to the open Ionian Sea exceeds $2 \times 10^{6} \mathrm{~m}^{3} / \mathrm{yr}$ (Poulos et al., 2002). Along the northern part of the coastal area under investigation, the longshore sediment transport is directed towards the east being more pronounced at its western part (units B and C) and induced mostly by the N and NE windgenerated waves (Fig. 6) The highest value belongs to the unit E that presents a NNW-SSE shoreline orientation.

Most of the beach zone consists of mixed material, while relatively higher percentage of sandy material is present in unit E (Fig. 4). Along the shoreline associated with torrential in origin cones, the dominant material consists of shingles and cobbles with the exception of the active mouth of Xerias torrent, where fine-grained sediment is also present. The aforementioned absence of finegrained material is attributed to low terrestrial influxes and the action of marine processes although are not particularly strong (e.g. wave activity). The latter is in accordance with the overall erosive picture of the beach zone that maybe also attributed (partially) to the continuing rise of sea level during upper Holocene (IPCC, 2007). 
Table 2. Weighted average (with respect to frequency of occurrence of each wind direction) of the wind velocity ( $\mathrm{Ua}$ ) and the corresponding prognostic values of significant wave period (Tp) and height (Hs) for the five successive units (A-E) of the coastal area under investigation.

\begin{tabular}{|c|c|c|c|c|c|c|c|c|c|c|c|c|c|c|c|}
\hline & \multicolumn{3}{|c|}{ UNIT A } & \multicolumn{3}{c|}{ UNIT B } & \multicolumn{3}{c|}{ UNIT C } & \multicolumn{3}{c|}{ UNIT D } & \multicolumn{3}{c|}{ UNIT E } \\
\hline & Ua & Tp & Hs & Ua & Tp & Hs & Ua & Tp & Hs & Ua & Tp & Hs & Ua & Tp & Hs \\
\hline W & 2.38 & 1.33 & 0.08 & - & - & - & - & - & - & - & - & - & - & - & - \\
\hline NW & 4.20 & 1.85 & 0.16 & 3.61 & 2.59 & 0.28 & 3.16 & 2.13 & 0.20 & 2.80 & 1.97 & 0.15 & - & - & - \\
\hline N & 2.80 & 1.55 & 0.10 & 2.80 & 1.63 & 0.12 & 2.80 & 1.80 & 0.14 & 2.80 & 1.97 & 0.15 & 2.80 & 1.98 & 0.16 \\
\hline NE & - & - & - & 3.18 & 2.18 & 0.20 & 3.18 & 2.17 & 0.20 & 3.72 & 2.14 & 0.27 & 3.18 & 2.26 & 0.21 \\
\hline E & - & - & - & 2.16 & 2.52 & 0.20 & 2.79 & 2.18 & 0.23 & - & - & - & 2.16 & 2.33 & 0.18 \\
\hline
\end{tabular}

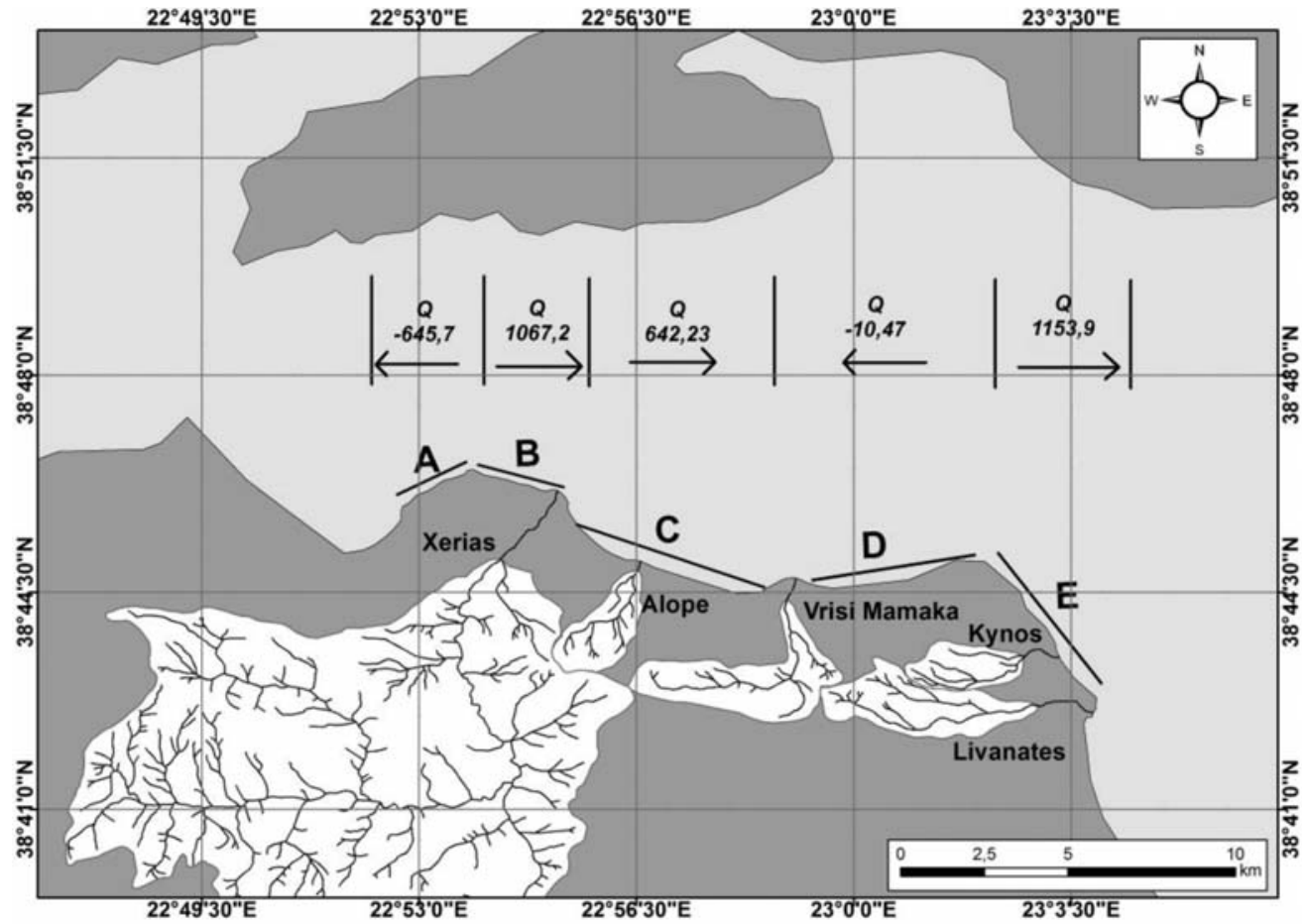

Fig. 6: Map depicting the division of the coastal area into 5 sub-units (A-E) according to their orientation. Q stands for annual potential longshore sediment transport, measured in $\mathrm{m}^{3}$. 
Table 3. Estimated values of potential longshore sediment transport $(\mathrm{Q})$ per wind direction at the different units (A-E).

\begin{tabular}{|c|c|c|c|c|c|}
\hline & UNIT A & UNIT B & UNIT C & UNIT D & UNIT E \\
\hline $\mathbf{W}$ & 10.4 & - & - & - & - \\
\hline $\mathbf{N W}$ & 16.7 & 1277.5 & 438.2 & 611.2 & - \\
\hline $\mathbf{N}$ & 672.8 & 127.1 & 614.3 & -624.2 & 932.4 \\
\hline $\mathbf{N E}$ & - & -330.7 & -240.5 & 2.5 & 260.2 \\
\hline $\mathbf{E}$ & - & -6.7 & -169.8 & - & -38.7 \\
\hline Total & -645.7 & +1067.2 & +642.2 & -10.5 & +1153.9 \\
\hline
\end{tabular}

\section{Conclusions}

The presence of raised coastal landforms such as marine terraces, notches and beachrocks, suggests that the formation and evolution of the coastal zone under investigation is controlled primarily by the endogenic processes and in particular the neotectonic uplift. Nearshore marine processes play a secondary role influencing mainly beach zone shape and granulometry.

\section{References}

Armijio R., Meyer B., King G.C.P., Rigo A. and Papanastassiou D., 1996. Quaternary evolution of the Corinth rift and its implications for the Late Cenozoic evolution of the Aegean, Geoph. J. Int., 126, $11-53$

Baud, A., Jenny, C., Papanikolaou, D., Sideris, C., Stampfli, G.M. 1991. New observations on Permian stratigraphy in Greece and geodynamic implication. Bull. Geol. Soc. Greece, XXV/1, 187-206.

Carter, R.W.G., 1988. Coastal Environments, London: Academic Press, 617p.

Clement, B. 1983. Évolution géodynamique d'un secteur des Hellénides: l'Attique septentrionale. Annales Société géologique du Nord, 101, 87-96.

Cundy, A., Gaki-Papanastassiou, K., Papanastassiou, D., Maroukian, H., Frogley, M. and T. Cane, 2009, Geological and geomorphological evidence of recent coastal uplift along a major Hellenic normal fault system (the Kamena Vourla fault zone, NW Evoikos Gulf, Greece)., Marine Geology, (under publication).

Doutsos, T., Kokkalas S. 2001. Stress and deformation in the Aegean region. J. Struct. Geol., 23, 455-472.

Doutsos, T., Poulimenos, G., 1992. Geometry and kinematics of active faults and their seismotectonic significance in the western Corinth-Patras rift (Greece). J. Struct. Geol., 14, 689-699.

Eliet, P., and R. Gawthorpe, 1995. Drainage development and sediment supply within rifts, examples from the Sperchios basin, central Greece. J. Geol. Soc. London, 152, 883-893.

Gaki-Papanastasiou K., Maroukian H., Papanastassiou D. and Palyvos N., 1999 Geo-archaeology and morphotectonics in the area of Livanates-Kynos-Arkitsa during the Holocene, Proc. 5th National Gongr. of the Geological Society of Greece., 101-111.

Guernet, C., 1971. Etudes géologiques en Eubée et dans les régions voisines (Grèc). Thèse d'Etat Univ. Paris, 395 pp., Paris.

IPCC, 2007. Climate Change 2007: The physical Science Basis Summary for Policymakers Contribution of Working Group I to the Fourth Assessment Report of the Intergovernmental Panel on Climate 
Change, Richard Alley et al, Geneva, 18 pp.

Kokkalas, S., Xypolias, P., Koukouvelas, I., and Doutsos, T., 2006. Postcollisional contractional and extensional deformation in the Aegean region, in Dilek, Y., and Pavlides, S., eds., Post-collisional tectonics and magmatism in the Mediterranean region and Asia: Geological Society of America Special Paper 409, p. 97-123, doi: 10.1130/2006.2409(06)

Komar, P.D., 1976. Beach Processes and Sedimentation, New Jersey, Englewood Cliffs: Prentice-Hall, Inc., 429pp.

Meijer, P.T., Wortel, M.J.R., 1997. Present-day dynamics of the Aegean region: A model analysis of the horizontal pattern of stress and deformation. Tectonics 16, 879-895.

Pirazzoli P., 1996, Sea level changes the last 20000 years. J Wiley p.211

Poulos S.E., Voulgaris G., Kapsimalis V., Collins M. and Evans G., 2002. Sediment fluxes and the evolution of a riverine-supplied tectonically-active coastal system: Kyparissiakos Gulf, Ionian Sea (eastern Mediterranean). (In:) Jones S.J., Frostick L.E. (eds) Sediment Flux to Basins: Causes, Controls and Consequences. Journal of the Geological Society, 191: 247-266.

Roberts, S., and J. Jackson 1991. Active normal faulting in central Greece: an overview, in The Geometry of Normal Faults, A.M. Roberts, G. Yielding, and B. Freeman (Editors), Geological Society Special Publications 56, Geological Society, London, 125 - 142.

Roberts, G. P. and Koukouvelas, I., 1996. Structural and seismological segmentation of the Gulf of Corinth Fault System: implications for models of fault growth. Annali di Geophysics XXXIX, 619-646.

US Army Corps of Engineers, 1984. Shore Protection Manual, Washington DC 21314.

Van Andel, T.H. and C. Perissoratis 2006. Late Quaternary depositional history of the North Evoikos Gulf, Aegean Sea, Greece, Mar. Geol., 232, 157-172.

Westaway, R., 1991. Continental extension on sets of parallel faults: observational evidence and theoretical models. In: Roberts, A.M., Yielding, G., Freeman, B. (Eds.), The Geometry of Normal Faults. Geol. Soc. London Spec. Publ. 56, 143-169.

Woodward J.C., 1995. Patterns of Erosion and suspended Sediment Yield in Mediterranean River Basins. (In:) Forster I.D.L. Gurnell A.M. \& Webb B.W.(Eds), Sediment and water quality in river catchment. Wiley, Chichester, 365-389.

Hellenic Army service, Topographic maps 1:50.000 sheets Pelasgia, Elateia, Livanates, 1979.

Institute of Geology and Mineral Exploration, Geological maps 1:50.000 sheets Pelasgia, Elateia, Livanates, 2006. 